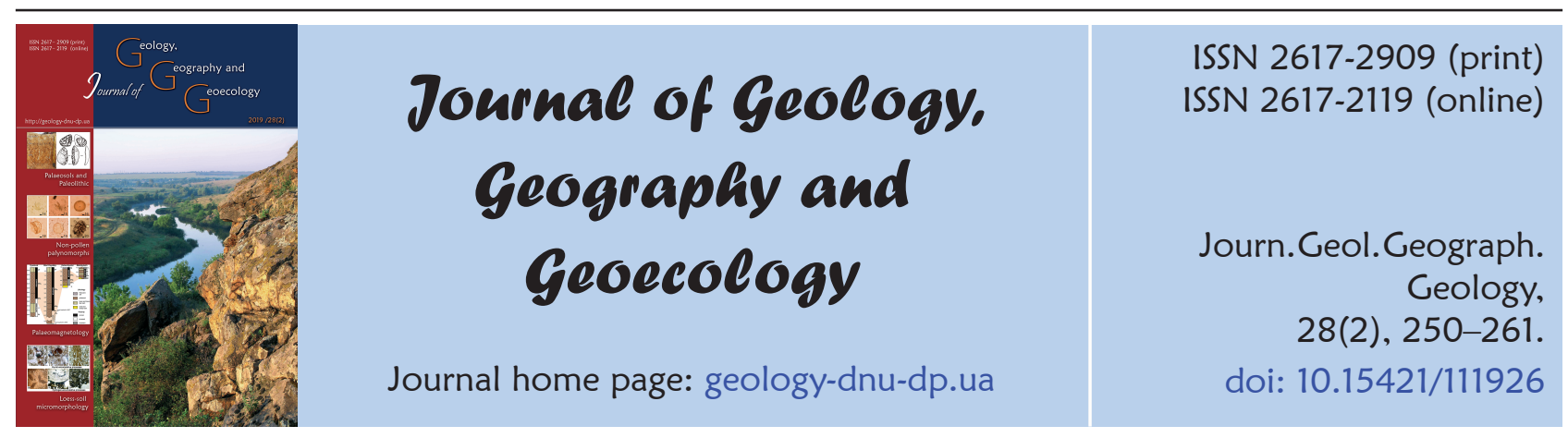

Dykan N.I.

Journ. Geol. Geograph. Geoecology, 28(2), 250-261.

\title{
Stratigraphy of the Pliocene deposits of the Black Sea (Ukraine) according to evidence from ostracods (Arthropoda, Crustacea)
}

\author{
N.I. Dykan
}

Institute of Geological Sciences of the National Academy of Sciences of Ukraine, Kyiv, Ukraine, e-mail:natalidykan@gmail.com

Received: 18.02 .2019

Received in revised form: 05.03.2019

Accepted: 29.04.2019

Abstract. This article presents a detailed analysis of the taxonomic composition of the Pliocene (Kimmerian, Kujalnikian) and Eopleistocene (Gurian) ostracods in the northern part of the Black Sea. It presents the patterns of the stratigraphic position of the fossil ostracods in the Miocene - Quaternary and their geographic distribution in Western and Eastern Europe (the Pannonian Basin, the Dacian Basin, the Euxinian basin of the Paratethys) and the Mediterranean region.We determined the characteristic species for the Kimmerian, Kujalnikian and Gurian in the northern part of the Black Sea. We established a change in the taxonomic composition of ostracods at the Pliocene (Kujalnikian)/Eopleistocene (Gurian) boundary, namely the disappearance of a large number of Pliocene species and the appearance of new species. Ten species disappeared in the Kujalnikian: Cyprideis pontica, Euxinocythere (M.) crebra, Amnicythere mironovi, Camptocypria lobata, Loxoconcha subcrassula, Loxoconcha verticalitercostata, Xestoleberis (X.) cellulocus, Xestoleberis (P.) communis, Candona (C.) expressa, Ilyocypris caspiensis; one species Amnicythere postbissinuata appeared in the Gurian. The brackish water species Cyprideis pontica is the Kujalnikian index species. The stratigraphic position of Cyprideis pontica in the Mediterranean Basin, Pannonian Basin, Dacian Basin, Euxinian Basin (Black Sea) in the Miocene-Quaternary is analyzed. The time of the disappearance of Cyprideis pontica in the Mediterranean, Pannonian and Dacian basins (Messinian, Pontian/Zanclean, Dacian, Kimmerian boundary) and in the Black Sea (Kujalnikian/Gurian boundary) is established. The diagnostic morphological features of the shell Cyprideis pontica (morphology of the surface pore canals) are established and described, which allows us to place this species in the Neogene deposits. Surface pore canals are different shape, sievetyped, deepened in relation to the surface of the valve. Sieve-shaped lamella contains 110-270 internal pores. The internal pores have a staggered shape, the diameter of the osculum of the internal pore is $302-994 \mathrm{~nm}$; diameter of the central pore is $977 \mathrm{~nm}-1.8 \mu \mathrm{m}$ ). The evolution of Cyprideis pontica, which was separated from the parent species Cyprideis torosa in the Late Miocene, was reconstructed. In the occupation of a new ecological niche with a reduced oxygen content in deeper water biotopes, in the process of adapting to the conditions of hypoxia and necessity of increasing the volume of water filtration, there was a restructuring of the morphology of the surface pore canals of the shell Cyprideis torosa. This involved an increase in the size of the sieve-shaped lamella, the number of internal pores in the sieve-shaped lamella and the size of the osculum of the inner pore. A new morphotype Cyprideis pontica was thus formed within the existing Parathetys-Mediterranean basins. It had a mosaic, ecologically isolated range that coincided geographically or overlapped with the range of the species Cyprideis torosa (sympatric evolutionary speciation). The range of Cyprideis pontica and the dynamics of its populations in the Euxinian Basin during the Sarmatian-Kujalnikian have been reconstructed.

Keywords: stratigraphic boundary, Pliocene, Quaternary, Ostracoda

\section{Стратиграфія пліоценових відкладів Чорного моря (Україна) за остракодами (Arthropoda, Crustacea)}

\author{
H.I. Дикань
}

Інститут геологічних наук НАН Украӥни, м. Київ, Украӥна, е-mail: natalidykan@mail.ru

Анотація. Дано детальний аналіз таксономічного складу пліоценових (кіммерійських, куяльницьких) і еоплейстоценових (гурійських) остракод у північній частині Чорного моря. Встановлено закономірності стратиграфічного положення викопних остракод у міоцені-квартері та географічного поширення в межах Західної і Східної Європи (Панонський, Дакійський, Євксинський басейни Паратетису) і Середземноморської області. Визначено характерні види для кіммерійського, куяльниць- 
кого і гурійського регіоярусів для північної частини Чорного моря. Встановлено зміну таксономічного складу остракод на границі пліоцену (куяльницького регіоярусу)-еоплейстоцену (гурійського регіоярусу), а саме зникнення у куяльницький час значної частки пліоценових видів, появі у гурійський час нових видів. Видом-індексом куяльнику у Чорному морі є солонуватоводних вид Сурrideis pontica. Проаналізовано стратиграфічне положення Сурrideis pontica у Середземноморскому, Панонському, Дакійському, Евксінському (Чорноморському) басейнах у міоцені-квартері. Встановлено час зникнення Сургіdеis роntica у Середземноморському, Панонському і Дакійському басейнах (границя мессіну, понту -занклію, дакію, кімерію), у Чорному морі (границя куяльника-гурия). Встановлено та описано діагностичну морфологічну ознаку черепашки Сурrideis роntica (морфологію поверхневих порових каналів), яка дозволяє чітко ідентифікувати цей вид у неогенових відкладах. Поверхневі порові канали різної форми, ситовидні, заглиблені по відношенню до поверхні стулки. Ситовидна пластинка містить 110-270 внутрішніх пор. Внутрішні пори мають стовбчасту форму, діаметр вустя внутрішньої пори $302-994$ nт; діаметр центральної

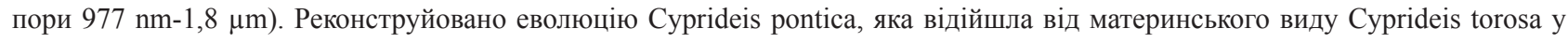
пізньому міоцені. При занятті нової екологічної ніши із зниженим вмістом кисню у більш глибоководних біотопах, в процесі адаптації виду до умов гіпоксії та пов'язаною з цим необхідністю у збільшенні об'ємів фільтрації води відбулась перебудова морфології поверхневих порових каналів черепашки Сурrideis torosa (збільшення розміру ситовидної пластинки, кількості внутрішніх пор у пластинці та розміру вустя внутрішньої пори).В межах існуючих басейнів Паратетис-Середземноморської області сформувався новий морфотип Суprideis pontica iз мозаїчним. екологічно ізольований ареалом, що географічно співпадав чи перекривався з ареалом виду Сурrideis torosa (симпатричне еволюційне формоутворення). Реконструйовано ареали Cyprideis pontica та динаміку його популяцій в Евксинському басейні протягом сармату-куяльнику.

Ключові слова: стратиграфічна граниия, пліоцен, квартер, остракоди

Introduction. In the Geologic Time Scale (2012) the biostratigraphic divisions of the Pliocene deposits and the Quaternary base (2.588 Ma, between the Gelasian and Piacenzian (Riccardi, 2009) was substantiated by chronostratigraphy, event stratigraphy, magnetostratigraphy, radiometric dating $\left({ }^{40} \mathrm{Ar} /{ }^{39} \mathrm{Ar}\right.$ dating, ${ }^{14} \mathrm{C}$ and ${ }^{230} \mathrm{Th} / 234 \mathrm{U}$ dating, $\mathrm{U} / \mathrm{Pb}$ dating, ${ }^{87} \mathrm{Sr} /{ }^{86} \mathrm{Sr}$ ), climate change and Milankovich cycles (sedimentation cycles), and oxygen and carbon isotopes $\delta^{18} \mathrm{O}, \delta^{13} \mathrm{C}$ curves. Palaeontological characteristic of the Gelasian and Piacenzian derive from different faunal groups (mammals, planktonic foraminifera, calcareous nannofossils, diatoms, radiolarians, dinoflagellates). However, formally, the Neogene-Quaternary boundary is uniquely substantiated on the appearance at the beginning of the Gelasian of dinoflagellate cysts of Spiniferites pachyderma and Invertocysta tabulata (middle part of D21, northwestern Europe) and the radiolarian Pterocanium prismatium (RN12b, northwestern Europe), as well as the disappearance at the end of the Piacenzian of the radiolarian Anthocyrtidium jenghisi (zone RN12a; northwestern Europe) and the planktonic foraminiferan Dentoglobigerina altispira (zone PL 5, Pacific Ocean). The Pliocene-Quaternary boundary $(2,588 \mathrm{Ma})$ in the Paratethys region is compared with the boundary of the megacycle Ge1 without paleontological substantiation. It is located in the upper part of the Pannonian and within the Kimmerian (Fig. 29. Neogene-Quaternary Regional Subdivisions: Hilgen, Lourens, Van Dam, 2012).

In the Quaternary stratigraphic scheme for Ukraine, the Pliocene/Quaternary boundary is placed at the level between the Kujalnikian (Gelasian) and the Gurian (Calabrian) at 1.81 Ma (Stratigraphic Code of Ukraine, 2012). This is based on the appearance in the Gurian of the molluscs Dreissena distanta, $D$. polymorpha, Didacna digressa, D. giriana, Modiolus phaseolinus, nannoplankton Pseudoemiliania, Gephyrocapsa oceanica, Emilia hyxleyi, as well as the disappearance of the Kujalnikian form Dreissena theodori. The planktonic Foraminifera Ammonia beccarii, Ammonia tepida, Fissurina porecta, Cananifera parcarae, nanoplankton Discoaster brouweri and D. pentaradiatus (Tabl. 17.) are represented in the stratigraphic scheme of Cenozoic deposits of the Ukrainian sector of the Black Sea: Stratigraphic Code of Ukraine, 2012). The National Stratigraphic Committee of Ukraine adopted the decision on the recognition of the ICS Pliocene/Quaternary boundary at the level of 2.588 Ma (Resolution of the NSCU dated April 18, 2018: Geological Journal, 2018). Accordingly, the Pliocene/ Quaternary boundary is now placed at a lower level in the Kujalnikian horizon, which needs additional palaeontological fauna-floristic substantiation.

The purpose of this article is to detail the microfaunistic characteristics (using ostracods) of the Pliocene (Kimmerian, Kujalnikian) and Eopleistocene (Gurian) marine sediments, and to substantiate the Pliocene/Quaternary boundary in the northern part of the Black Sea.

Neogene ostracods of the Paratethys and Mediterranean regions and the Quaternary ostracods of western and eastern Europe, the Black Sea, Caspian Sea and Mediterranean Sea have been well studied in their systematic, ecological, zoogeographical and palaeogeographical aspects. They are used for detailed relative-age determination and correlation of marine deposits, but fossil ostracods as a biostratigraphic tool have not been used in the international stratigraphic scales of the Neogene-Quaternary (Geologic Time Scale, 2004, 2012) and Ukrainian stratigraphic schemes of the Neogene-Quaternary (Stratigraphic 
Code of Ukraine, 2012). This biostratigraphic analysis using ostracods was the first of its kind.

Fossil ostracods are a uniquely informative group of fossil microorganisms. In sediments, ostracods are often the only (and usually numerous) representatives of the fossil fauna. They had a predominantly autochthonous type of burial, often beautifully preserved or at least with a sufficient degree of conservation of the shell to allow species identification. Local and regional biostratigraphic divisions in the Neogene-Quaternary deposits of the Black Sea are distinguished using ostracods (Dykan, 2011; Dykan, 2012; Dykan 2016 a, b, c, d, f). Therefore, the application of fossil ostracods to stratigraphic correlation schemes, as a biostratigraphically important group of fossil microorganisms, is scientifically sound and expedient.

Material and methods of research. The NeogeneQuaternary and recent ostracods of the Black Sea were collected over a period of forty years (1978-2017) from outcrops on the northern coast of the Black Sea (from the Danube to the Taman Peninsula), well cores (Odessa region, Kerch Peninsula, Taman Peninsula, the estuaries of the northwest coast of the Black Sea) and stations (the shelf and continental slope of the morphology) (Dykan, 2006). Electronic-microscopy, taphonomic, statistical, population, geochemical and facial methods, and zoogeographical analyses have been used in the study of fossil ostracods. The determination of the geological ages of the marine deposits was based on biostratigraphic and ecological criteria derived from ostracods. The biostratigraphy is based on the presence of index species; groups of fossil ostracods, which have the upper and lower boundaries, well established first and last appearances of characteristic species; in the presence of periods of optimum of ostracod species (genera); on the ratio of zoogeographical species (Mediterranean, Caspian) and species of different ecological specialization (marine, brackish water, freshwater). Literary sources on the stratigraphic position and geographical distribution of fossil ostracods in the Holarctic belt were also taken into account.

Results and their analysis. In the northern part of the Black Sea, Pliocene deposits are represented by Kimmerian and Kujalnikian horizons. The Kimmerian deposits are distributed on the western shelf from the mouth of the Tiligul estuary, on the Crimean continental slope from isobaths $287 \mathrm{~m}$ to $1750 \mathrm{~m}$, to the southern slope of the Kerch-Taman shelf to the

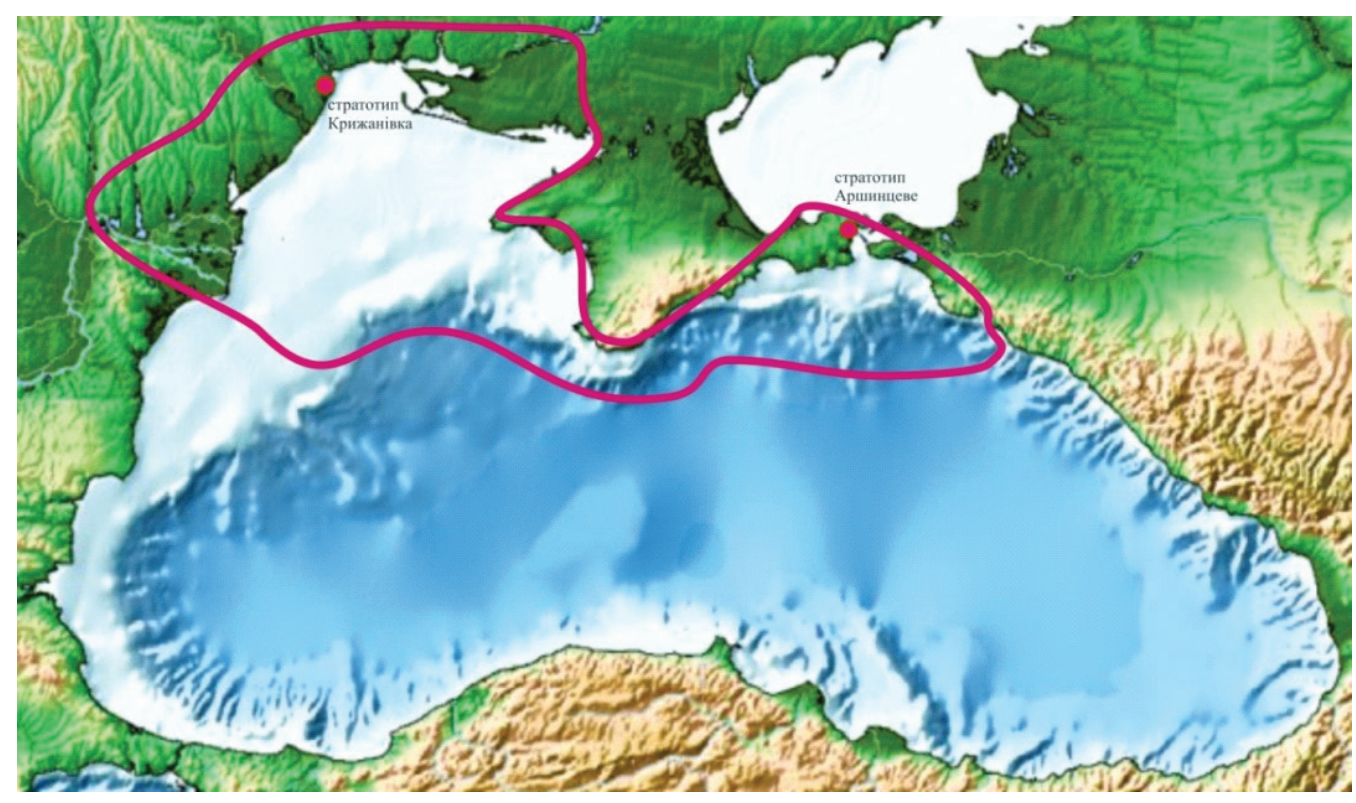

Fig. 1. Map of the research area in the northern part of the Black Sea

northern part of the Black Sea, SRV NASU) (Fig. 1).

The biostratigraphic conclusions were based on the systematic study of fossil ostracods (the identification of species, the principles and criteria for the determination of taxonomic features, the estimation of the taxonomic weight of the morphological features, the determination of diagnostic features of the different taxonomic ranks, taxonomic diagnoses, unified method of the description of shell isobaths $150-200 \mathrm{~m}$. They are presented by a layer of sandy clayey silts on the north-western shelf; oolitic iron ores with clay layers in the Crimean continental slope; iron-bearing sandstone on the eastern part of the northwestern shelf and the Kerch shelf. The thickness of the Kimmerian deposits decreases from east to west and is 40-50 m (Semenenko, 1987; Shuraev, 2015). The lectostratotype of the Kimmerian is the section near the village Arshintsevo (Kamish-Burun) 
(Stratigraficheskij slovar SSSR. Paleogen. Neogen. Chetvertichnaya sistema, 1982).

The Kimmerian ostracods comprise 19 genera and 38 species. They include some inherited Pontian ostracod genera (Cyprideis, Tyrrhenocythere, Euxinocythere (Maeotocythere), Amnicythere, Loxoconchissa (Loxocaspia), Xestoleberis (Pontoleberis), Advenocypris, Bacunella, Camptocypria, Caspiocypris, Pontoniella) as well as some species. The peculiarity of the Pontian relic species in the Kimmerian deposits is that it is poor in crustaceans, which is also manifested in small shells. Typical species of the beginning of the Kimmerian are Tyrrhenocythere amnicola donetziensis Dub., Loxoconchissa (Loxocaspia) eichwaldi (Liv.), Loxoconchissa (Loxocaspia) immodulata (Step.), Loxoconchissa (Loxoconchissa) bairdyi (G.W. Müll.), Loxoconcha lepida Step., Pseudocytherura pontica Dub., Camptocypria gracilis (Liv.), Caspiocypris merculiensis Vek., Candona (Candona) angulata G.W. Müll., Cypria candonaeformis (Schw.), Ilyocypris caspiensis (Neg.) (Table. 1). In the northwestern part of the Kimmerian Basin, ostracods formed stable associations of the species Bacunella dorsoarcuata, Camptocypria acronasuta, Camptocypria lobata, Cyprideis torosa, Tyrrhenocythere azerbaidjanica (Liv.), and Cryptocyprideis bogatschovi. The Kimmerian species Camptocypria lobata and Bacunella dorsoarcuata had large shells in comparison with the Pontian individuals. This is a clear marker for separating the Pontian and Kimmerian deposits in the northern part of the Black Sea (Dykan, 2016 a).

The Kujalnikian deposits occur in wells on the shelf and in the deep-water zone of the continental slope; their areal distribution coincides with the Kimmerian deposits (Semenenko, 1987). They are presented by sand, silts, sandstones and clay with a total thickness of $40-50 \mathrm{~m}$. The lectostratotype of the
Kujalnikian is the section near the village Kryzhanivka (Odesa region, Ukraine) (Stratigraficheskij slovar SSSR. Paleogen. Neogen. Chetvertichnaya sistema, 1982).

Kujalnikian ostracods comprise 19 genera and 42 species. A characteristic feature of the Kujalnikian ostracods is the transitional Kimmerian-Kujalnikian type fauna, where $62 \%$ are Kimmerian relics: Pseudocytherura pontica, Cyprideis torosa (Jones), Cyprideis pontica Krstič, Tyrrhenocythere amnicola donetziensis Dub., Tyrrhenocythere azerbaidjanica (Liv.\&Agal.), Euxinocythere (Maeotocythere) crebra (Schn.), Amnicythere palimpsesta (Liv.), Amnicythere multituberculata (Liv.), Amnicythere mironovi (Schn.), Loxoconchissa (Loxocaspia) eichwaldi (Liv.), Loxoconchissa (Loxocaspia) immodulata (Step.), Loxoconcha lepida (Step.), L. subcrassula Suz., Xestoleberis (Pontoleberis) laevis (Karm.), Camptocypria acronasuta (Liv.), Camptocypria gracilis (Liv.), Caspiocypris labiata (Zal.), Bacunella dorsoarcuata (Zal.), Pontoniella acuminata (Zal.), Cryptocyprideis bogatschovi (Liv.), Advenocypris centropunctata (Suz.), Candona (Candona) expressa, Candona (Candona) angulata (G.W. Müll.), Candona (Candona) elongata (Schw.), Cypria candonaeformis (Schw.), Cypria arma (Schn.). Caspian immigrants accounted for $28 \%$ of the total number of species: Caspiocypris lobata (Zal.), Caspiocypris merculiensis Vek., Cyprideis ruggierii Dec., Amnicythere spectabilis (Mark.), Loxoconcha bulgarica Car., Loxoconcha verticalitercostata Dyk., Candona (Candona) neglecta Sars, Candona (Eucandona) balatonica Dad., Cyprinotus salinus (Br.), Ilyocypris bradyi Sars, Il. gibba (Ramd.), Il. caspiensis (Neg.). Mediterranean immigrants account for $10 \%$ of the total number of species: Aurila notata (Reuss), Xestoleberis (Pontoleberis) communis G.W. Müll., Xestoleberis (Xestoleberis) cellulosus Vek., X. (Xestoleberis) chanakovi Liv.\&Agal. (Fig. 2).

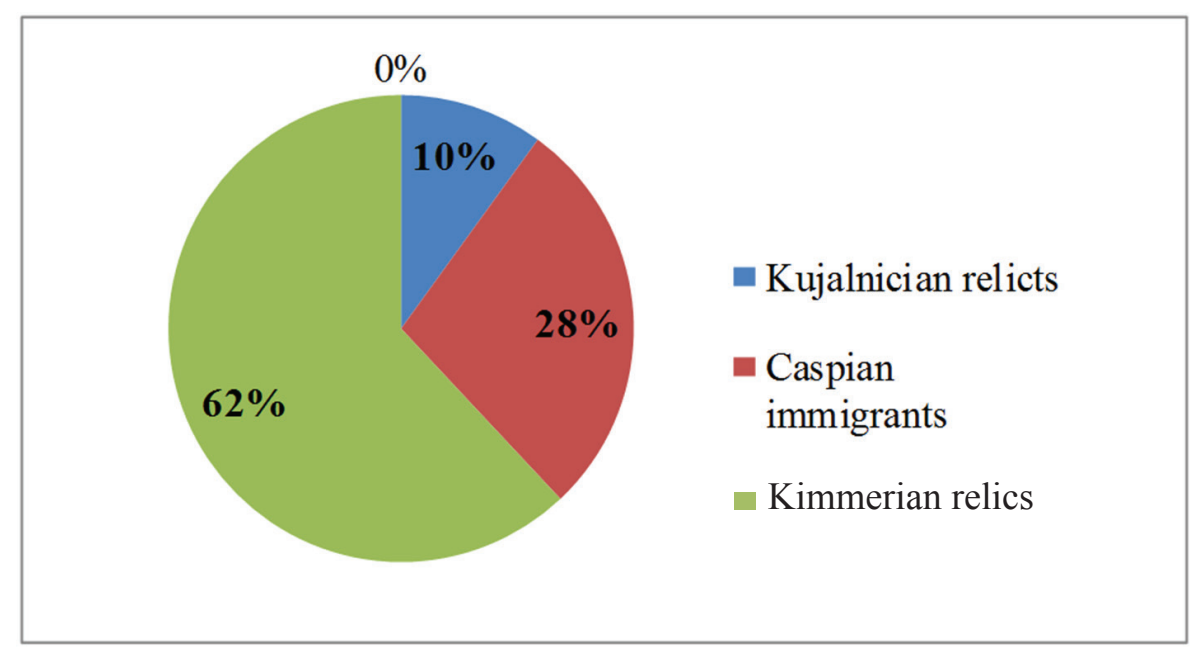

Fig. 2. The ratio of zoogeographic groups of ostracods in Kujalnikian deposits 
Table 1. Stratigraphic position of ostracodes in Neogene-Quaternary deposits of the northern part of the Black Sea

\begin{tabular}{|c|c|c|c|c|c|c|c|c|c|c|c|c|c|c|}
\hline \multirow{2}{*}{ Species composition of ostracods } & \multicolumn{2}{|c|}{ Pliocene } & \multicolumn{2}{|c|}{\begin{tabular}{|c|c|} 
Eopleis \\
tocene
\end{tabular}} & \multicolumn{5}{|c|}{ Neopleistocene } & \multicolumn{5}{|c|}{ Holocene } \\
\hline & $\mathrm{km}$ & $\mathrm{kj}$ & $\mathrm{gu}$ & $\mathrm{ch}$ & de & $\mathrm{eu}$ & $\mathrm{kg}$ & $\mathrm{pk}$ & ne & $b g$ & $\mathrm{vz}$ & $\mathrm{kl}$ & fn & $\mathrm{gz}$ \\
\hline \multicolumn{15}{|l|}{ Cyprideis torosa** } \\
\hline \multicolumn{15}{|l|}{ Cyprideis pontica** } \\
\hline \multicolumn{15}{|l|}{ Cyprideis ruggierii** } \\
\hline \multicolumn{15}{|l|}{ Cyprideis acervumis** } \\
\hline \multicolumn{15}{|l|}{ Cyprideis compleporiferus** } \\
\hline \multicolumn{15}{|l|}{ Cyprideis subtorosus $* *$} \\
\hline \multicolumn{15}{|l|}{ Cryptocyprideis bogatschovi* } \\
\hline \multicolumn{15}{|l|}{ Cytheridea sakarauli*** } \\
\hline \multicolumn{15}{|c|}{ Paracyprideis naphtatscholana*** } \\
\hline \multicolumn{15}{|c|}{ Tyrrhenocythere amnicola donetziensis** } \\
\hline \multicolumn{15}{|c|}{ Tyrrhenocythere azerbaidjanica** } \\
\hline \multicolumn{15}{|c|}{ Tyrrhenocythere trabzonensis** } \\
\hline \multicolumn{15}{|c|}{ Tyrrhenocythere sollertissimorete** } \\
\hline \multicolumn{15}{|l|}{ Tyrrhenocythere pontica** } \\
\hline \multicolumn{15}{|c|}{ Tyrrhenocythere complexolacunisae** } \\
\hline Hemicytheria dubokensis** & & & & & & & $?$ & & & & & & & \\
\hline Aurila dubowskyi*** & & & & & & & & & & & & & & \\
\hline Aurila notata*** & & & & & & & & & & & & & & \\
\hline Urocythereis margaritifera** & & & & & & & & & & & & & & \\
\hline Euxinocythere (E.) relicta** & & & & & $?$ & & & & & & & & & \\
\hline Euxinocythere (E.) magma* & & & & & & & & & & & & & & \\
\hline Euxinocythere (E.) multipun & & & & & & & & & & & & & & \\
\hline Euxinocythere (E.) bosqueti & & & & & $?=$ & & & & & & & & & \\
\hline Euxinocythere (M.) bacuana & & & & & & & & & & & & & & \\
\hline Euxinocythere (M.) lopatici’ & & & & & & & & & & & & & & \\
\hline Euxinocythere (M.) crebra** & & & & & & & & & & & & & & \\
\hline Euxinocythere (M.) praebaq & & & & & & & & & & & & & & \\
\hline Amnicythere quinquetuberc & & & & & & & & & & & & & & \\
\hline Amnicythere resupina** & & & & & & & & & & & & & & \\
\hline Amnicythere plana** & & & & & & & & & & & & & & \\
\hline Amnicythere postbissinuata: & & & & & & & & & & & & & & \\
\hline Amnicythere longa** & & & & & & & & & & & & & & \\
\hline Amnicythere palimpsesta** & & & & & & & & & & & & & & \\
\hline Amnicythere multitubercula & & & & & & & $?=$ & & ? & & & & & \\
\hline Amnicythere polymorpha** & & & & & & & & & & & & & & \\
\hline Amnicythere spectabilis** & & & & & & & & & & & & & & \\
\hline Amnicythere striatocostata* & & & & & & & & & & & & & & \\
\hline Amnicythere cymbula** & & & & & & & & & & & & & & \\
\hline Amnicythere mironovi** & & & & & & & & & $?$ & & & & & \\
\hline Amnicythere volgensis** & & & & & & & & & & & & & & \\
\hline Amnicythere pirsagatica** & & & & & & & & & & & & & & \\
\hline Amnicythere gracilloides** & & & & & & & & & & & & & & \\
\hline
\end{tabular}

Note: ${ }^{*}$ - freshwater species; ${ }^{* *}$ - brackishwater species; ${ }^{* * *}$ - marine species 
Continuation of Table 1. Stratigraphic position of ostracods in Neogene-Quaternary deposits of the northern part of the Black Sea

\begin{tabular}{|c|c|c|c|c|c|c|c|c|c|c|c|c|c|c|}
\hline \multirow{2}{*}{ Species composition of ostracods } & \multicolumn{2}{|c|}{ Pliocene } & \multicolumn{2}{|c|}{$\begin{array}{c}\text { Eopleis } \\
\text { tocene }\end{array}$} & \multicolumn{5}{|c|}{ Neopleistocene } & \multicolumn{5}{|c|}{ Holocene } \\
\hline & $\mathrm{km}$ & $\mathrm{kj}$ & $\mathrm{gu}$ & $\mathrm{ch}$ & de & eu & $\mathrm{kg}$ & $\mathrm{pk}$ & ne & $b g$ & $\mathrm{vz}$ & $\mathrm{kl}$ & $\mathrm{fn}$ & gz \\
\hline \multicolumn{15}{|l|}{ Amnicythere histriana*** } \\
\hline \multicolumn{15}{|l|}{ Calistocythere flavidofusca $* * *$} \\
\hline \multicolumn{15}{|l|}{ Calistocythere diffusa*** } \\
\hline \multicolumn{15}{|l|}{ Calistocythere cristata*** } \\
\hline \multicolumn{15}{|l|}{ Mediocytherideis apatoica** } \\
\hline \multicolumn{15}{|l|}{ Loxoconchissa (L.) petasus** } \\
\hline \multicolumn{15}{|l|}{ Loxoconchissa (L.) eichwaldi** } \\
\hline \multicolumn{15}{|l|}{ Loxoconchissa (L.) babazananica** } \\
\hline \multicolumn{15}{|l|}{ Loxoconchissa (L.) immodulata** } \\
\hline \multicolumn{15}{|c|}{ Loxoconchissa (L.) praeimmodulata** } \\
\hline \multicolumn{15}{|l|}{ Loxoconchissa (L.) endocarpus** } \\
\hline \multicolumn{15}{|l|}{ Loxoconchissa (L.) bairdyi** } \\
\hline \multicolumn{15}{|l|}{ Loxoconcha subcrassula** } \\
\hline Loxoconcha ljuljevi*** & & & & & & & & & & & & & & \\
\hline Loxoconcha lepida** & & & & & & & & & & & & & & \\
\hline Loxoconcha bulgarica*** & & & & & & & & & & & & & & \\
\hline Loxoconcha gibboides $* * *$ & & & & & & & & & & & & & & \\
\hline Loxoconcha rhomboidea $* * *$ & & & & & & & & & & & & & & \\
\hline Loxoconcha verticalitercostata & & & & & & & & & & & & & & \\
\hline Loxoconcha granulata*** & & & & & & & & & & & & & & \\
\hline Loxoconcha rennata $* * *$ & & & & & & & & & & & & & & \\
\hline Loxoconcha globosa $* * *$ & & & & & & & & & & & & & & \\
\hline Loxoconcha elliptica*** & & & & & & & & & & & & & & \\
\hline Loxoconcha aestuarii $* * *$ & & & & & & & & & & & & & & \\
\hline Loxoconcha pontica*** & & & & & & & & & & & & & & \\
\hline Palmoconcha agilis*** & & & & & & & & & & & & & & \\
\hline Paracytheridea paulii*** & & & & & & & & & & & & & & \\
\hline Paradoxostoma variabile*** & & & & & & & & & & & & & & \\
\hline Paradoxostoma guttatum*** & & & & & & & & & & & & & & \\
\hline Paradoxostoma naviculum*** & & & & & & & & & & & & & & \\
\hline Paradoxostoma simile*** & & & & & & & & & & & & & & \\
\hline Pseudocytherura pontica*** & & & & & & & & & & & & & & \\
\hline Cushmanidea tschernjawskiii** & & & & & & & & & & & & & & \\
\hline Cushmanidea bacescoi*** & & & & & & & & & & & & & & \\
\hline Carinocythereis carinata $* * *$ & & & & & & & & & & & & & & \\
\hline Carinocythereis rubra*** & & & & & & & & & & & & & & \\
\hline Costa edwardsii runcinata*** & & & & & & & & & & & & & & \\
\hline Xestoleberis (P.) laevis** & & & & & & & & & & & & & & \\
\hline Xestoleberis (P.) communis*** & & & & & & & & & & & & & & \\
\hline Xestoleberis (X.) decipiens*** & & & & & & & & & & & & & & \\
\hline Xestoleberis (X.) acutipensis*** & & & & & & & & & & & & & & \\
\hline Xestoleberis (X.) aurantia*** & & & & & & & & & & & & & & \\
\hline Xestoleberis $(\mathrm{X}$.$) cornelii****$ & & & & & & & & & & & & & & \\
\hline Xestoleberis (X.) cellulosus $* * *$ & & & & & & & & & & & & & & \\
\hline Xestoleberis (X.) elongata*** & & & & & & & & & & & & & & \\
\hline Xestoleberis $(\mathrm{X}$.$) chanakovi***$ & & & & & & & & & & & & & & \\
\hline
\end{tabular}


End of Table 1. Stratigraphic position of ostracods in Neogene-Quaternary deposits of the northern part of the Black Sea

\begin{tabular}{|c|c|c|c|c|c|c|c|c|c|c|c|c|c|c|}
\hline \multirow{2}{*}{ Species composition of ostracods } & \multicolumn{2}{|c|}{ Pliocene } & \multicolumn{2}{|c|}{$\begin{array}{c}\text { Eopleis } \\
\text { tocene }\end{array}$} & \multicolumn{5}{|c|}{ Neopleistocene } & \multicolumn{5}{|c|}{ Holocene } \\
\hline & $\mathrm{km}$ & $\mathrm{kj}$ & $\mathrm{gu}$ & $\mathrm{ch}$ & de & eu & $\mathrm{kg}$ & $\mathrm{pk}$ & ne & $\mathrm{bg}$ & $\mathrm{vz}$ & $\mathrm{kl}$ & fn & gz \\
\hline \multicolumn{15}{|l|}{ Semicytherura sulcata*** } \\
\hline \multicolumn{15}{|l|}{ Semicytherura euxinica*** } \\
\hline \multicolumn{15}{|l|}{ Cytherois cepa*** } \\
\hline \multicolumn{15}{|l|}{ Camptocypria acronasuta** } \\
\hline \multicolumn{15}{|l|}{ Camptocypria gracilis** } \\
\hline \multicolumn{15}{|l|}{ Camptocypria lobata** } \\
\hline \multicolumn{15}{|l|}{ Caspiocypris labiata** } \\
\hline \multicolumn{15}{|l|}{ Caspiocypris merculiensis** } \\
\hline \multicolumn{15}{|l|}{ Bacunella dorsoarcuata** } \\
\hline \multicolumn{15}{|l|}{ Pontoniella acuminata** } \\
\hline \multicolumn{15}{|l|}{ Advenocypris centropunctata* } \\
\hline \multicolumn{15}{|l|}{ Limnocythere inopinata* } \\
\hline \multicolumn{15}{|l|}{ Metacypris cordata* } \\
\hline Darwinula stevensoni* & & & & & & & & & & & & & & \\
\hline Candona (C.) expressa* & - & & & & & & & & & & & & & \\
\hline Candona (C.) candida* & & & & & & & & & & & & & & \\
\hline Candona (C.) angulata* & & & & & & & & & & & & & & \\
\hline Candona (C.) iliensis* & & & & & & & & & & & & & & \\
\hline Candona (C.) neglecta* & & & & & & & & & & & & & & \\
\hline Candona (C.) elongata* & & & & & & & & & & & & & & \\
\hline Candona (C.) rawsoni* & & & & & & & & & & & & & & \\
\hline "Candona (C.) angulata* & & & & & & & & & & & & & & \\
\hline Candona (E.) balatonica* & & & & & & & & & & & & & & \\
\hline Candona (E.) caucasica* & & & & & & & & & & & & & & \\
\hline Typhlocypris rostrata* & & & & & & & & & & & & & & \\
\hline Typhlocypris compressa* & & & & & & & & & & & & & & \\
\hline Cyclocypris ovum* & & -? & & & & & & & & & & & & \\
\hline Cyclocypris laevis* & & & & & & & & & & & & & & \\
\hline Cypria candonaeformis & & & - & & & & 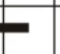 & & & & & & & \\
\hline Cypria arma* & & & & & & & & & & & & & & \\
\hline Cypria lacustris* & & & & & & & & & & & & & & \\
\hline Cyprinotus salinus* & & & & & & & & & & & & & & \\
\hline Ilyocypris bradyi* & & & & & & & & & & & & & & \\
\hline Ilyocypris gibba* & & & & & & & & & & & & & & \\
\hline Ilyocypris caspiensis* & & ? & & & & & & & & & & & & \\
\hline Eucythere ex.gr.declivis* & & & & & & & & & & & & & & \\
\hline Eucypris clavata* & & & & & & & & & & & & & & \\
\hline Zonocypris membranae* & & & & & & & & & & & & & & \\
\hline Herpetocypris reptans* & & & & & & & & & & & & & & \\
\hline Heterocypris incongruens* & & & & & & & & & & & & & & \\
\hline Bairdia raripila $* * *$ & & & & & & & & & & & & & & \\
\hline Bythocythere schornikovi $* * *$ & & & & & & & & & & & & & & \\
\hline Cytheropteron rotendatum*** & & & & & & & & & & & & & & \\
\hline Cytheridea acuminata*** & & & & & & & & & & & & & & \\
\hline Heterocytherideis reticulata*** & & & & & & & & & & & & & & \\
\hline
\end{tabular}


$\square$ marine specis $\quad \square$ freshwater species $\square$ brackishwater species

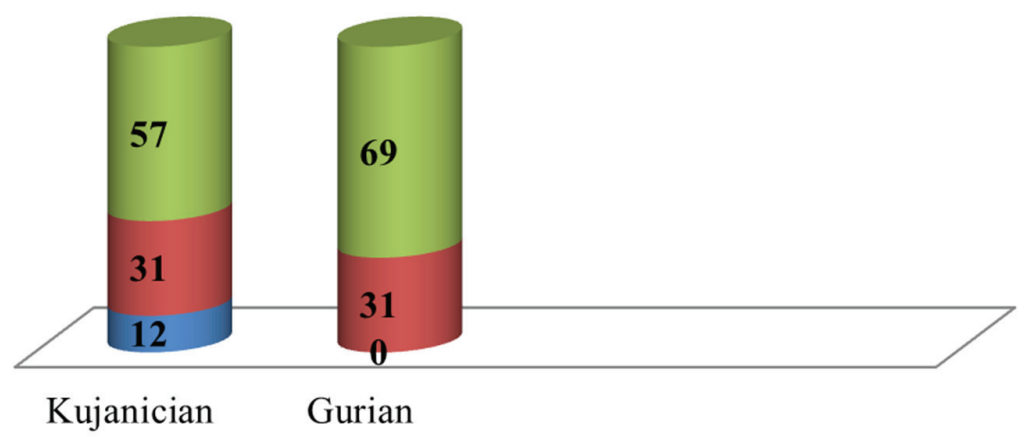

Fig. 3. Percentage ratio of different ecologically specialized species in the Kujalnikian and Gurian deposits of the northern part of the Black Sea

Typical species of the Kujalnikian ostracods are Cyprideis ruggierii Dec., Aurila notata (Reuss), Amnicythere spectabilis (Mark.), Loxoconcha bulgarica Car., Xestoleberis (Xestoleberis) chanakovi, Candona (Eucandona) balatonica Dad., Cypria arma (Schn.) (Dykan, 2006, 2016 a). Kujalnikian ostracod associations had a brackish water-freshwater-marine composition: brackish water species accounted for $57 \%$, freshwater $-31 \%$, marine $-12 \%$ of the total number of species (Fig. 3).

Gurian deposits are embedded low down in the marine Quaternary deposits and they are mosaically distributed between isobaths $10-90 \mathrm{~m}$ in the northwestern and northeastern shelf of the Black Sea. They are represented by silts and clays with a total thickness of up to $20 \mathrm{~m}$.

Gurian ostracods total 11 genera and have a poor species composition (17 species). They are presented by Miocene-Pliocene relics, which accounted for $94 \%$ of the total: Loxoconchissa (Loxoconchissa) bairdi (G.W. Müll.), Loxoconchissa (Loxocaspia) babazananica (Liv.), Bacunella dorsoarcuata (Zal.), Pontoniella acuminata (Zal.), Tyrrhenocythere amnicola donetziensis Dub., Tyrrhenocythere azerbaidjanica (Liv.), Camptocypria acronasuta (Liv.), Camptocypria gracilis (Liv.), Amnicythere palimpsesta (Liv.), Cyprideis torosa (Jones), Cypria candonaeformis (Schw.), Ilyocypris gibba (Ramd.), Il. bradyi Sars, Advenocypris centropunctata (Suz.), Cryptocyprideis bogatschovi (Liv.), Darwinula stevensoni (Brady \& Rob.). The index species of the beginning of the Gurian is Amnicythere postbissinuata (Neg.) (Dykan, 2016 a) (Table 1). Gurian ostracod associations had a brackish water-freshwater composition: brackish water species dominated (accounting for $69 \%$ of the total number of species ), with freshwater ostracods comprising $31 \%$; Fig. 3).

The Pliocene/Quaternary boundary, as defined by ostracods between the Kujalnikian and Gurian horizons in the northern part of the Black Sea, is based on the change in taxonomic composition of ostracods, with the disappearance of Pliocene species and the appearance of new Quaternary ones. Ten species disappeared in the Kujalnikian: Cyprideis pontica Krstič, Euxinocythere (Maetocythere) crebra (Schn.), Amnicythere mironovi (Schn.), Camptocypria lobata (Zal.), Loxoconcha subcrassula Suz., Loxoconcha verticalitercostata Dyk., Xestoleberis (Xestoleberis) cellulosus Vek., Xestoleberis (Pontoleberis) communis G.W. Müll., Candona (Candona) expressa Karm., Ilyocypris caspiensis (Neg.): and one species, Amnicythere postbissinuata, appeared in the Gurian (Figs. 4, 5).

Also, the biostratigraphic marker of the Kujalnikian in the Black Sea is Cyprideis pontica Krstić, 1968 (Dykan, 2016 b). The brackish-water

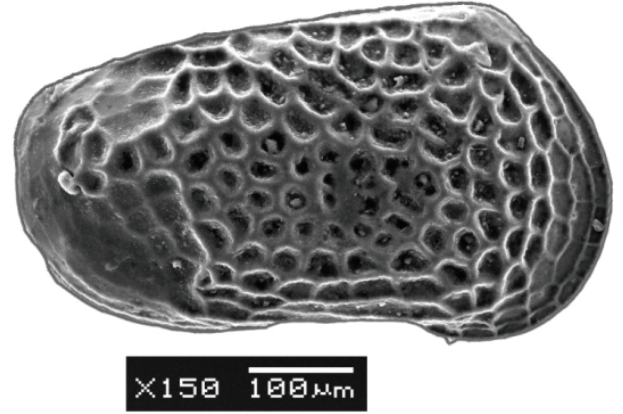

Fig. 4. Index species of the Gurian Amnicythere postbissinuata (Neg.), collection No. 2567-5-132/9, right valve, female, adult, Gurian horizon, Taman Peninsula, Akhtanizivsky station 

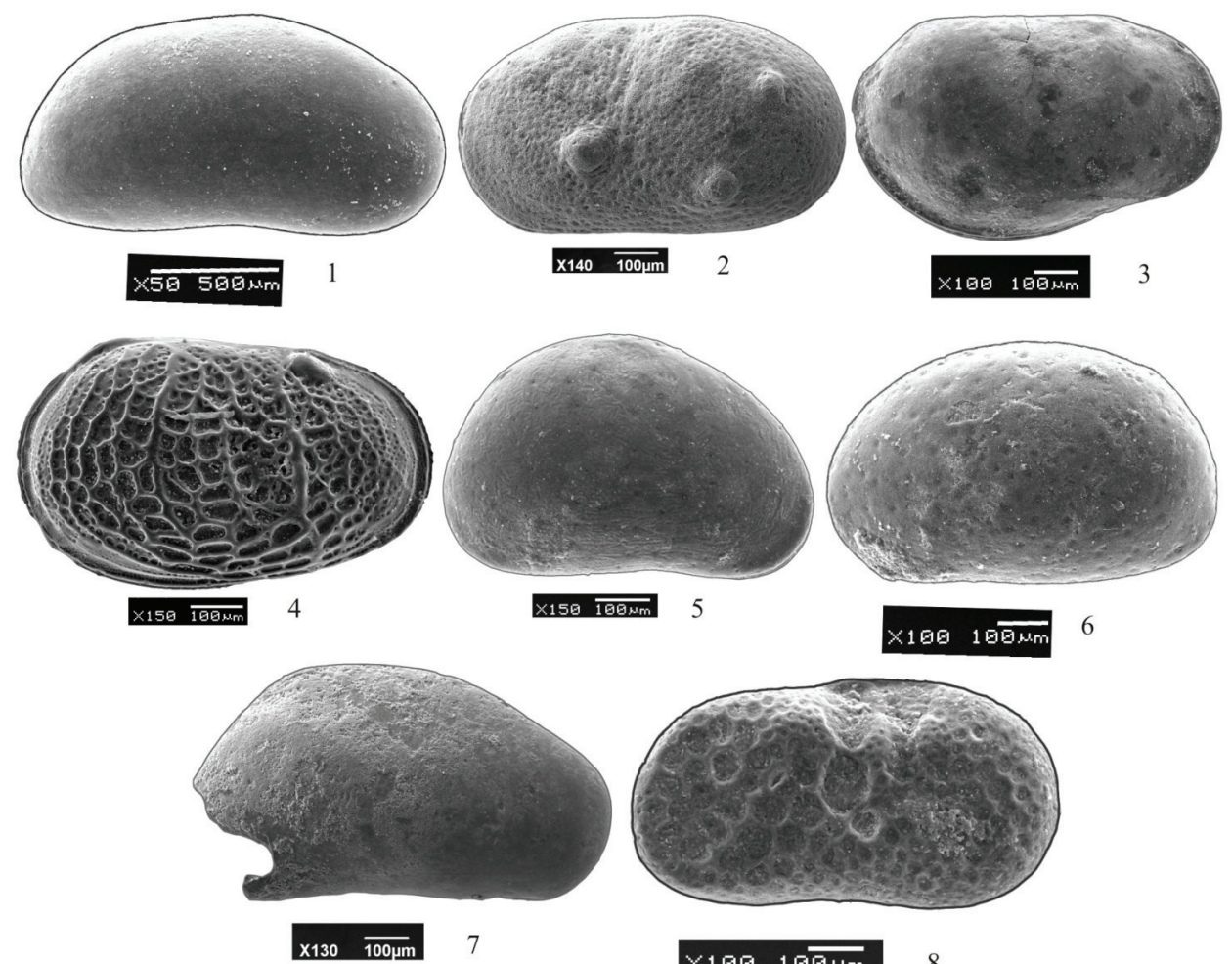

7
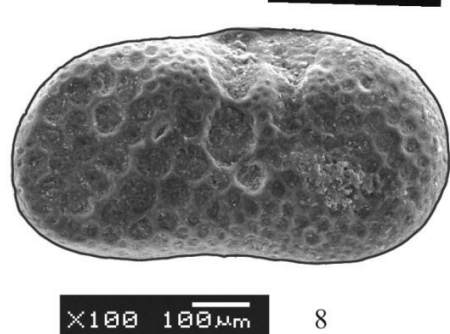

8

Fig. 5. Characteristic species of the Pliocene that disappeared at the Kujalnikian/Gurian boundary:

1 - Camptocypria lobata (Zal.), collection No. 2567-64/21, left valve, adult, Kimmerian horizon, northeastern part of the Black Sea; 2 - Cyprideis pontica Krstić, collection No. 2567-6/2, left valve, female, adult, Kimmerian horizon, northwestern part of the Black Sea; 3 - Loxoconcha subcrassula Suz., collection No. 2567-21/16, left valve, female, adult, Kujalnikian horizon, northwestern part of the Black Sea; 4 - Loxoconcha verticalitercostata Dyk., collection No. 2567-6/17, left valve, female, adult, Kimmerian horizon, northwestern part of the Black Sea; 5 - Xestoleberis (Xestoleberis) cellulosus Vek., collection No. 2567-86/20, right valve, female, adult, Kujalnikian horizon, northwestern part of the Black Sea; 6 - Xestoleberis (Pontoleberis) communis Müll., collection No. 256781/19, left valve, adult, Kujalnikian horizon, northwestern part of the Black Sea; 7 - Candona (Candona) expressa Karm., collection No. 2567-5-1/26, right valve, adult, Kimmerian horizon, Taman Peninsula, Zaliznyy Rih section; 8 - Ilyocypris caspiensis (Neg.), collection No. 2567-5-129/26, right valve, adult, Kujalnikian horizon, Taman Peninsula, Akhtanizivsky station

species Cyprideis pontica has a narrow stratigraphic range (in the upper half of the Middle MiocenePliocene) and a widespread geographic distribution within Western and Eastern Europe (Pannonian Basin,
Dacian Basin, Euxinian Basin of Paratethys), and the Mediterranean region. The stratigraphic position of the species Cyprideis pontica in the Mediterranean region (eastern Mediterranean Basin, Crete and

Table 1. Stratigraphic position of Cyprideis pontica Krstić in Parathetys-Mediterranean region

\begin{tabular}{|c|c|c|c|c|c|}
\hline Period & Epoch & $\begin{array}{l}\text { MEDITERRANEAN BASIN } \\
\text { (ATNTS2004) }\end{array}$ & $\begin{array}{c}\text { PANNONIAN BASIN } \\
(\mathrm{SCU}, 2012)\end{array}$ & $\begin{array}{c}\text { DACIAN BASIN } \\
\text { (SCU, 2012) }\end{array}$ & $\begin{array}{l}\text { EVKSINIAN BASIN } \\
\text { (SCU 2012) }\end{array}$ \\
\hline $\begin{array}{l}\text { QUATER } \\
\text { NARY } \\
\end{array}$ & $\begin{array}{c}\text { LOWER } \\
\text { PLEEISO- } \\
\text { CENE }\end{array}$ & CALABRIAN & LOWER PI & CENE & GURIAN \\
\hline \multirow{12}{*}{ 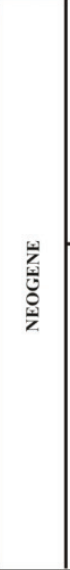 } & \multirow{4}{*}{$\begin{array}{l}\frac{1}{2} \\
\frac{\mathbf{n}}{2} \\
\stackrel{0}{2}\end{array}$} & $2.588 \quad$ GELASIAN & \multirow{2}{*}{ RUMUNIAN } & \multirow{3}{*}{ RUMUNIAN } & \multirow{3}{*}{ KUJALNICIAN } \\
\hline & & 3.600 PIACENZIAN & & & \\
\hline & & ZANCLEAN & \multirow[t]{2}{*}{ DACIAN } & & \\
\hline & & 5.332 & & DACIAN & KIMMERIAN \\
\hline & \multirow{8}{*}{ 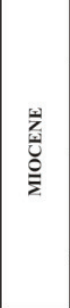 } & MESSINIAN & PONTIAN & PONTIAN & PONTIAN \\
\hline & & & \multirow{2}{*}{ PANNONIAN } & MAEOTIAN & MAEOTIAN \\
\hline & & 11.608 & & \multirow{2}{*}{ SARMATIAN } & \multirow{2}{*}{ SARMATIAN } \\
\hline & & \multirow{3}{*}{ SERRAVALLIAN } & SARMATLAN & & \\
\hline & & & \multirow{4}{*}{ BADENIAN } & & KONKIAN \\
\hline & & & & & KARAGANIAN \\
\hline & & \multirow{2}{*}{ LANGHIAN } & & & CHOKRAKIAN \\
\hline & & & & & TARKHANIAN \\
\hline
\end{tabular}


northern Greece) covers the upper SerravallianMessinian interval (Mostafawi, 1989, 1996); in the Pannonian Basin (Austria, Slovenia, northern and eastern Serbia) the Upper Pannonian-Upper Pontian (Gross et al, 2008); in the Dacian Basin (northern Bulgaria, Romania) the Pontian (Krstić et al, 1989; Olteanu, 1989); and in the Euxinian Basin (Black Sea) (northern shelf, the Indo-Kuban depression) the Sarmatian-Kujalnikian (Dykan, 2016 a, b). The species Cyprideis pontica disappears at the boundary of the Late Miocene (Messinian, Pontian) and the Pliocene (Zanclean, Dacian, Kimmerian) (5.33 Ma) in the Mediterranean, Pannonian Basin and Dacian Basin (The Geologic Time Scale, 2012) (Table 1). of water filtration, there was a reorganization of the morphology of the surface pore channels in the species Cyprideis torosa. This involved an increase in the size of the sieve-shaped lamellae, the number of internal pores in these lamellae and the size of the osculum of the inner pore, and a change in the shape of the inner pore on the stack with a rim along the perimeter. As a result of these evolutionary processes, a new morphotype Cyprideis pontica was formed within the Paratethys-Mediterranean basins. It occupied a mosaic, ecologically isolated area that coincided geographically or overlapped with the area occupied by the species Cyprideis torosa (sympatric evolutionary process) (Fig. 6).

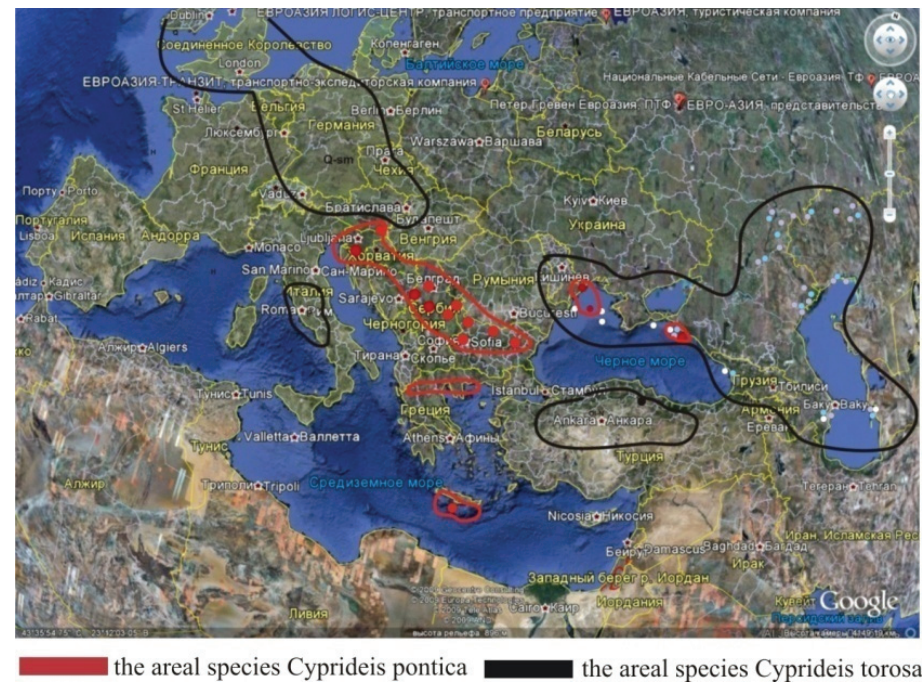

Fig 6. Map of the range of Cyprideis pontica Krstić and Cyprideis torosa (Jones) in the Paratethys-Mediterranean region (Middle Miocene-Pliocene)

Cyprideis pontica continued to exist during the Sarmatian-Kujalnikian in the Euxinian Basin. High density monotypic populations of the species were formed in the deep-water habitats of the eastern part of the Black Sea (Indo-Kuban depression) during the Sarmatian-Maeotian. The area with Cyprideis pontica declined in the Pliocene to the northwestern part of the sea, where this species was still widespread in the shallow coastal biotope, though with a population of low density. Cyprideis pontica was rare in the Kujalnikian, its few populations represented only, or mainly by, larvae. The species had disappeared in the Black Sea by the Kujalnikian/Gurian boundary.

Cyprideis pontica is a phylogenetic branch of the species Cyprideis torosa - separating from the parent species $C$. torosa in the Late Miocene. As a result of the occupation of a new ecological niche in deeper water biotopes of the shelf and continental slope with a reduced oxygen content, part of the population of Cyprideis torosa went through a narrow specialization process. In the process of adaptation to hypoxia and the necessity to increase the volume
The morphology of the shell of Cyprideis pontica Krstić has a diagnostic feature (the morphology of the surface pore canals), which allows this species to be recognised in the Neogene deposits (Dykan, 2016 a, b). The surface pore canals have a different shape (rounded, oval, flower-shaped, irregularly elongated, irregularly oval), different sizes $(8-42 \mu \mathrm{m})$, sieve-typed, deepened in relation to the surface of the valve. The sieve-shaped lamella contains from 110 to 270 internal pores. The internal pores have a staggered shape and a round osculum (302-994 $\mathrm{nm}$ in diameter) with a rim along the perimeter. The central pore is located in the centre of the sieve-shaped lamella, deepened in relation to the surface of the valve, with a round osculum (977 nm-1.8 $\mu \mathrm{m}$ in diameter) (Fig. 7). Conclusions. A monographic study of the NeogeneQuaternary ostracods of the Black Sea, their stratigraphic position and geographical distribution in the Mediterranean-BlackSea-Caspian regionallow one to conclude that a change in the taxonomic composition and ecological specialization of ostracods occurred at the Kujalnikian/Gurian boundary in the northern part 

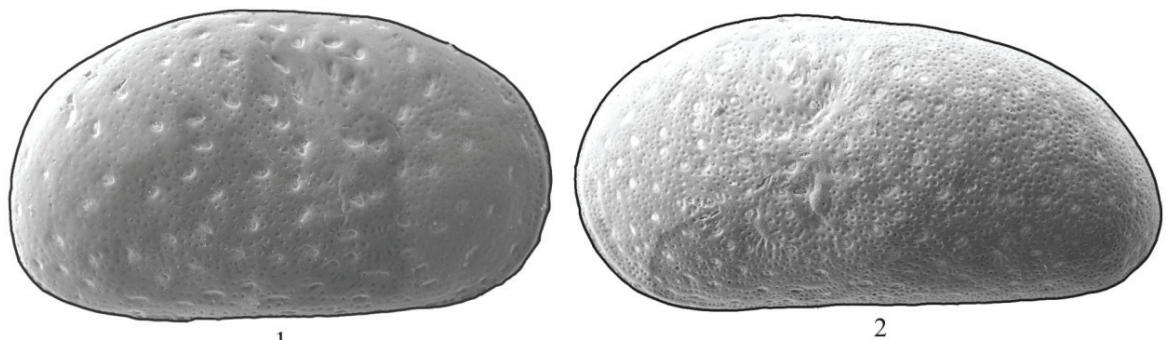

1
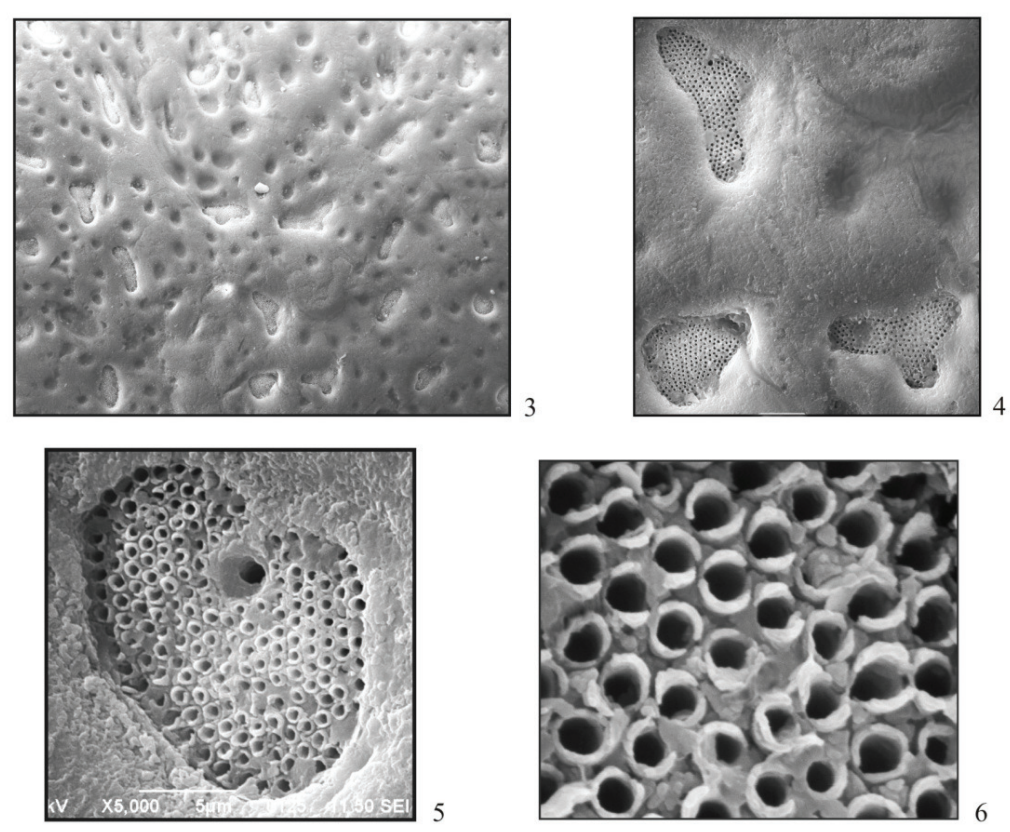

Fig. 7. Morphology of the fossil shell species Cyprideis pontica Krstić, 1968: 1 - right valve, female, adult, lateral external view (x 130), Upper Sarmatian horizon, north-western shelf of the Black Sea, drill hole 67; 2 - left valve, male, adult, lateral external view (x 95), Lower Maeotian horizon, north-western shelf of the Black Sea, drill hole 55; 3 fragment of the outer surface of the shell (x 250); 4 - surface porous canals (x 1000);); 5 - sieve-shaped lamella of the surface porous canal (x 5000); 6 - internal pores of the surface porous canal (x 13000) (Dykan, 2016)

of the Black Sea. 24\% of Pliocene species, including the index species Cyprideis pontica, disappeared in the Kujalnikian. Ostracod associations had a brackish water-freshwater-marine composition. In the Gurian, the new species Amnicythere postbissinuata appeared and brackish water-freshwater associations formed, with the domination of brackish water species.

\section{Rreferences}

Dykan N. I., 2006. Systematyka chetvertynnykh ostrakod Ukrainy [Systematics of Quaternary Ostracods of Ukraine]. IHN NANU, Kyiv(in Ukrainian).

Dykan N. I., 2011. Biostratigrafiya srednemiocenovyhnizhnepliocenovyh otlozhenij Tamanskogo poluostrova po ostrakodam [Biostratigraphy of the Middle-Miocene-Lower-Pliocene deposits of the Taman Peninsula by ostracods]. Geologicheskij zhurnal, № 3, 29-39 (in Russian).

Dykan N. I. 2012. Rozchlenuvannia pliotsenchetvertynnykh vidkladiv Chornoho moria (pivnichnyi shelf) za ostrakodamy [Determining of the age of the Pliocene-Quaternary deposits of the Black Sea (Northern shelf) byostracodes]. Tektonika i stratyhrafija, № 39, 111-131(in Ukrainian).

Dykan N. I,. 2016 a. Neohen-chetvertychnye ostrakody severnoi chasty Chornoho moria [NeogeneQuaternary ostracods of the northern part of the Black Sea]. Chetverta khvylia, Kyiv (in Russian).

Dykan N. I., 2016 b.Popov Kamen section. Ostracods:Paleontological Journal, 50 (10), 7781.

Dykan N. I., 2016 c. Taman ostracods.Paleontological Journal, 50 (10), 142-150.]

Dykan N. I., 2016 d.Taman section. Ostracods: Paleontological Journal, 50 (10), 104-107.

Dykan N. I., 2016 f. Zelensky-Panagia section. Ostracods: Paleontological Journal, 50 (10), 24-25.

Dykan N. I., 2016 g. Vid Cyprideis pontica Krstić, 1968 (Ostracoda, Crustacea) - indikator granicy pliocen-chetvertichnyh otlozhenij (severnaya chast Chernogo morya [View of Cyprideis pontica Krstić, 1968 (Ostracoda, Crustacea) - indicator of 
the boundary of Pliocene-Quaternary deposits (northern part of the Black Sea). Geologiya $i$ poleznye iskopaemye Mirovogo okeana, Kyiv, № 1 (43), 19-43 (in Russian).

Lourens L., Hilgen F., Shackleton N. J., Laskar J., Wilson D., 2004. The Neogene Period: The Geologic Time Scale, 409-440. doi.org/10.1017/ CBO9780511536045.022.

Geologic Time Scale, 2004. Editors: Gradstein F. M., Ogg J. G., Smith A. G. Cambridge University Press. doi.org/10.1017/CBO9780511536045.

Geologic Time Scale, 2012. Editors: Gradstein F. M. Ogg J. G. M. Schmitz, Ogg G. Gebrüder Borntraeger, Stuttgart, German. doi.org/10.1016/C2011-108249-8.

Gross M., Minati K., Danielopol D., Piller W., 2008. Environmental change and diversification of Cyprideis in the Late Miocene of the Styreal Basin (Lake Pannon, Austria). Senckenbergiana lethaea, 88 (1), 161-181.

Hilgen J., Lourens L.J., Van Dam J.A., 2012. The Neogene Period: The Geologic Time Scale, 923-964. doi. org/10.1016/C2011-1-08249-8.

Krstić N., Stancheva M., 1989.Ostracods of Eastern Serbia and Northern Bulgaria with notices on a Northern Turkey assemblage and some Mediterranean assemblage: Chronostratigraphe und Neostratotypen. Neogene der Westlichen (Zentrale) Paratethys. Pontien, VIII, 753-819.

Mostafawi N., 1996. Neogene Ostracodefaunen im Gebiet südlich von Thessaloniki (Nordgriechenland). Senckenbergiana lethaea, № 76 (1/2), 159-173.

Mostafawi N., 1989. Neogene ostracods of Chersonisos and Vrysses (Crete, Greece). Neues Jahrbuch für Geologie und Paläontologie. Abhandlungen, 178 (2), 183-201.
Olteanu R., 1989. La faune d'ostracodes ponties du Bassin Dacique: Chronostratigraphie und Neostyratotypen. Neogene der Westlichen (Zentrale) Paratetis. Pontien, VIII, 722-751.

Natsionalnyi stratyhrafichnyi komitet Ukrainy, 2018. Pro diyalnist Nacionalnogo stratygrafichnogo komitetu Ukrayiny [About the activities of the National Stratigraphic Committee of Ukraine]. Geologichnyj zhurnal, 2 (363), 95-100 (in Ukrainian).

Riccardi A. C., 2009. Ratification of the definition of the base of Quaternary System/Period (andtop of the Neogene System/Period), and redefinition of the base of the Pleistocene Series/Epoch (and top of the Pliocene Series/Epoch).IUGS. Retrieved from http://www.stratigraphy.org/upload/IUGS\%20 Ratification_Q\%20\&\%20Pleistocene.pdf.

Semenenko V. N., 1987. Stratigraficheskaya korrelyaciya verhnego miocena i pliocena Vostochnogo Paratetisa i Tetisa [Stratigraphic correlation of the Upper Miocene and the Pliocene of the Eastern Parathetis and Tetis]. Naukova dumka, Kyiv.

Shnyukov E. F., Shuraev I. N., 2015. Kimmerijskie peschaniki Krymskogo kontinentalnogo sklona [Cimmerian sandstones of the Crimean continental slope]: Stratotipovi ta oporni rozrizi fanerozojskih vidkladiv Ukraïni: suchasnij stan paleontologichnoï vivchenosti ta perspektivi podalshih doslidzhen. IHN NANU, Kyiv, 8, 215 221(in Russion).

Stratigraficheskij slovar SSSR. Paleogen. Neogen. Chetvertichnaya sistema, 1982. Leningrad.

Stratygrafichnyj kodeks Ukrayiny, 2012. [Stratigraphic Code of Ukraine]. Vidp. red. P.F.Gozhyk, 2-e vyd., Kyiv (in Ukrainian). 